\title{
VP-Shell Analysis for the Acquisition of Japanese Intransitive Verbs, Transitive Verbs, and Causatives*
}

\author{
Keiko Murasugi, Tomoko Hashimoto and Chisato Fuji \\ Nanzan University
}

\section{Abstract}

Japanese-speaking children erroneously produce intransitive forms instead of (di)transitive forms, and intransitive/(di)transitive forms instead of causative forms. Murasugi and Hashimoto (2004) provide a uniform account of such verbal errors following Larson's (1988) $v$-VP frame or VP-shell hypothesis: (i) the predicate-argument structures of large V's and small $v$ 's are acquired early, (ii) children assume [ \pm cause] $v$ to be phonetically null at one stage, and (iii) what requires time is the acquisition of the lexical form of each $\mathrm{V}$ and the forms in which [ \pm cause] small $v$ 's are realized. Adittional empirical evidence for their $v$-VP frame analysis is obtained from Sumihare Noji's database as well as from the observational data reported in the previous research. Based on the analysis of Japanese-speaking children's common errors widely observed in the previous literature and the two longitudinal studies presented in this article, in this paper, we develop the $v$-VP frame analysis for the acquisition of Japanese verbs and complex predicates.

\section{Introduction}

Verbal errors in child language are universally observed across languages. English- and Portuguese-speaking children, for example, produce such erroneous sentences as (1) and (2).

(1) Mommy, can you stay this open? ${ }^{1}$

(Bowerman 1974:143)

(2) Quem morreu ele?

'Who died him?' (die = kill)

(Figueira 1984:115)

In (1), the verb should be the transitive verb keep, but the child uses the intransitive verb stay instead. In (2), an example from Portuguese, the transitive verb 'kill' should be used, but the

\footnotetext{
*We would like to thank Mamoru Saito for discussions, comments, and suggestions for this paper. We also wish to express our gratitude to Sonja Eisenbeiss, William Snyder, Masumi Aono, Tomohiro Fujii, Yoshie Kabuto, Keiko Yano, Eriko Watanabe, Fusako Noji, Sachiko Kato, and Elizabeth Laurencot for the invaluable suggestions. We would like to thank Ann Kelly and the reviewers of Linguistics for their detailed comments.

An earlier version of this paper was presented at the workshop on three-place predicates held at the Max Planck Institute for Psycholinguistics (Nijmegen, Holland) in May, 2003, at the 2nd Yuelu Language Acquisition Workshop (Changsha, China) in September, 2005, at University of Connecticut (Storrs, U.S.A.) in March, 2006, and at workshops held at Nanzan University (Nagoya, Japan) from 2002 through 2006. We benefited from the comments by the participants and colleagues, and also from the stimulating discussion on three-place predicates and the acquisition of verbs from various perspectives at Max Planck, Yuelu Language Acquisition Workshop, UConn, and Nanzan University.

The research reported here is supported in part by the Nanzan University Pache Research Grant I-A and by JSPS Grant-in-Aid (C) (\#17520282) to Nanzan University.

1 The italicized form indicates non-adultlike usage.
} 
child wrongly employs the intransitive verb 'die.'

Similar errors are also observed in Japanese. It is well-known that Japanese-speaking children aged around 2 to 4, incorrectly use the intransitive form for the transitive verbs. Example (3) was reported by Otsu (2002: 185).

(3) Child (3;11):

Otootyan, mado ai-te.

daddy window is open-Request

(Intended meaning: 'Daddy, please open the window.')

Father:

Mado ake-te, daro.

window open-Request, isn't it?

'You mean, open the window.'

Child:

Un, mado ai-te yo.

yeah window is open-Request please

(Intended meaning: 'Yeah, Daddy, please open the window.')

Father:

Mado ake-te, dayo.

window open-Request, it should be

'It should be "Open the window".'

Child:

Iikara,mado ai-te yo, otootyan.

anyway window is open-Request please daddy

(Intended meaning: 'Anyway, please open the window, Daddy.')

(Otsu, 2002: 185[our translation])

In (3), the child asks his father to open the window. The child produces the erroneous intransitive imperative form ai-te (be open), instead of the correct transitive form ake-te (open), despite the direct correction from his father. The same type of error is observed in (4).

(4) Oniityan-ga aka nai.

brother-Nom be-opened not

Literal meaning: Brother is not opened (the door).

Intended meaning: Brother does not open (the door).

(Ito 2005: 3)

Errors in causatives have also been observed in the acquisition of various languages: Bowerman (1974) and Figueira (1984), for example, report that there is a stage when children cannot make the adult form for the causatives in English and Portuguese respectively.

(5) You can drink me the milk.

(Lord 1984:83)

(6) (...) este balanco vai te cair.

'This swing is going to fall you.'

Intended meaning: This swing will let you fall

(Figueira 1984:83)

In (5), the child tells his or her mother to let (or help) him or her drink milk. However, the causative verb is omitted. A similar example can be found in Portuguese as shown in (6).

The same type of errors can be elicited from Japanese as well. Japanese-speaking children, at around 2 to 4 years of age, produce such erroneous verb forms as (7). 
(7) Child (2;2):

Papa fuusen fukuran-de.

Daddy balloon swell-Request

(Intended meaning: Daddy, please blow up the balloon.)

Father:

Fukuran-de zyanaidesyo fukuramas-ite desyo.

swell-Request not isn't itblow up-Request isn't it

'It is not "fukuran-de" (swell). It should be "fukuramas-ite" (blow up).'

Child:

Fukuran-de.

swell

(Intended meaning: Blow up (the balloon).)

Father:

Fukuramas-ite.

blow up

'(You should say) blow up (the balloon).'

Child:

Fukuran-de. Fukuran-de.

swell swell

(Intended meaning: Blow up (the balloon)! Blow up (the balloon)!)

(Suzuki, 1987;172 [our translation])

The child asks his father to blow up the balloon. The farther provides the child with the correct lexical causative form fukuramas-ite (blow up), but it is never successful. The child continues producing the erroneous intransitive imperative form fukuran-de (swell).

This type of error is also frequently reported in the Japanese naturalistic studies. Some examples are given in (8).

a. Aririn-ga Yuutyan-ni pazyama-o kigae-ta. -Nom -Dat pajamas-Acc change-Past Literal meaning: Aririn changed clothes to Yuu. Intended meaning: Aririn helped Yuu into her clothes.

(Murasugi and Machida 1999:411)

b. Kukku nu-ide.

shoes take off-Request

Literal meaning: Please take off (a pair of) shoes.

Intended meaning: Please take my shoes off.

(Ito 1990:206)

c. Ak-(s)ase-te.

be open-Cause-Request

'Please open (the box of pins)'

(Ito 1990:70)

d. Kutu-o hake-sase-te.

shoes-Acc put on-Cause-Request

'Please put (a pair of) shoes on me.'

(Ito 1990:70)

In (8a), instead of the causative form kigae-sase-ta (lit. make-change-Past), the child employs the intransitive form kigae-ta (change-Past). In (8b), the child asks her mother to take off her shoes. The child produces the request form of the plain transitive verb nug- $u$ (take off), or $n u$-ide, although an adult would produce Kutu-o nug-ase-te, using the lexical causative form. In (8c), the child uses the unaccusative verb $a k-u$ (be open) instead of the transitive verb ake-ru (open), just as shown in (3)-(4). In addition, in (8c), furthermore, the child erroneously adds the causative suffix $-(s)$ ase to the verb, thereby producing the form *ak-ase-te. A similar example is found in (8d). Instead of the ditransitive verb hakas-u (shoe, transitive), the child 
uses the plain transitive verb hak-u (put on) or its potential form hak-e-ru (can put on). Like (8c), the child erroneously adds the causative suffix -sase to the verb erroneously in (8d), yielding the unacceptable verb *hake-sase-te.

The purpose of this article is to discuss such verbal errors in a systematic way within the framework of generative syntax. We first present an overview of Murasugi and Hashimoto (2004), who based their study on their longitudinal data of a Japanese-speaking child, Akkun, ${ }^{2}$ together with the child data reported in the previous researches, show that Japanese-speaking children make various types of errors in the process of the acquisition of agentive verbs and causatives. They account for those errors uniformly employing $v$-VP frame analysis and argue that children produce those errors because [ \pm cause] $v$ is assumed to be phonetically null at one stage. This analysis is further confirmed by Fuji (2006). We discuss Sumihare's data (Noji, 1974-1977) and conclude that the very same acquisition process observed by Murasugi and Hashimoto can be found in Sumihare's data (Noji, 1974-1977), thereby providing an additional evidence for the $v$-VP frame analysis.

This article is organized as follows: in Section 2, we introduce and discuss Murasugi and Hashimoto's $v$-VP frame analysis based on Larson's VP-shell hypothesis; in Section 3, we provide evidence obtained from the analysis of Sumihare's data; and in Section 4 we present our conclusion.

\section{Murasugi and Hashimoto (2004)}

\section{1. The Syntactic Representation of Agentive Verbs in $v$-VP frame}

Murasugi and Hashimoto's (2004) $v$-VP frame analysis on the acquisition of complex predicates provides evidence for Larson's (1988) VP-shell hypothesis. The $v$-VP frame is developed out of Larson's (1988) VP-shell analysis of ditransitive sentences such as (9).

(9) Mary gave it to John.

According to this analysis, there are two layers of VPs where the higher verb assigns the agent role to its Spec. This was generalized to all agentive sentences in Hale and Keyser (1993) and Chomsky (1995). That is, the agent role is always assigned by the higher verb, called small $v$ in distinction from the lower verb V, to its Spec. Thus, (9) and (10) can be represented as in (11) and (12), respectively.

Mary sank the boat.

\footnotetext{
2 The longitudinal study of Akkun was made from 1;9 until 7;0 of age. Tomoko Hashimoto, Akkun's mother, recorded the naturalistic data 25 hours a week on average, focusing on the full sentences Akkun produced. The purpose of the study was to see the synchronic change in the use of verbs in a Japanese individual child. The record was transcribed by Tomoko Hashimoto, and for confirmation, some target sentences were also elicited in natural context by Tomoko Hashimoto and Keiko Murasugi in the course of the longitudinal study.
} 
(11)

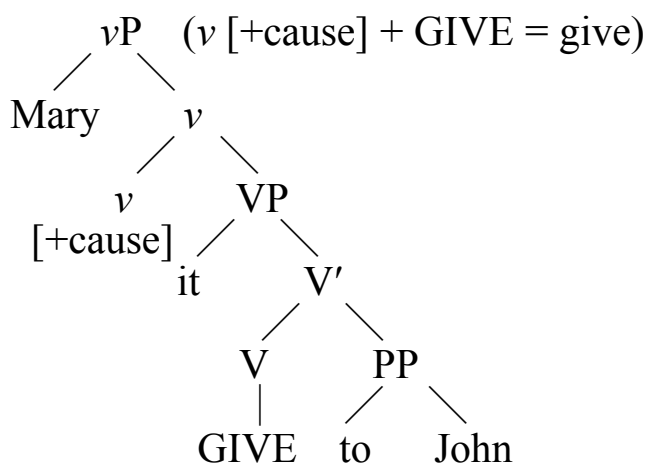

(12)

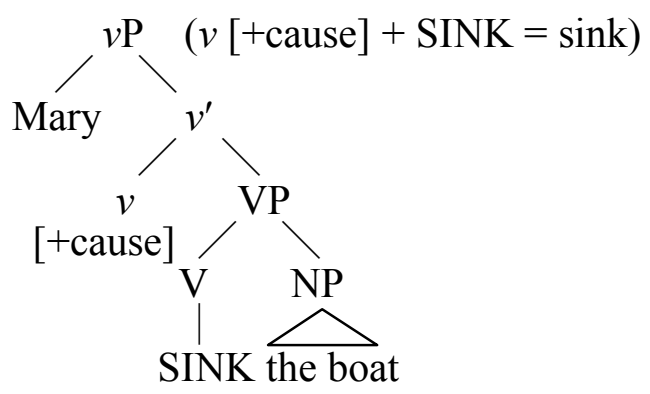

According to one version of this analysis, the verb give consists of two abstract verbs, as illustrated in (11). The higher one, small $v$, assigns the agent role to the subject of the sentence and takes a VP complement. It has the meaning of CAUSE. The lower one, capital GIVE, has the basic meaning of GO and takes two arguments, the theme and the goal. In (11), the agent is Mary, the theme is it, and the goal is John. The small v-projection represents the ACTIVITY or CAUSE, and the large V-projection represents the CHANGE OF STATE. The precise meaning of the ditransitive sentence (9) is that Mary DID something and that she CAUSED the event that it goes to John. The lower V is raised to the higher $v$-position, and then they together yield the lexical item give. And finally, the highest argument, Mary, moves to TP Spec, and assumes the subject position of the sentence. (12) is basically the same except that the event Mary CAUSED is the boat's sinking.

This analysis provides an elegant account for the alternation in (13) and also that in (14), discussed in detail in Baker (1996).

(13) a. Mary sank the boat.

b. The boat sank.

(14) a. John passed the ring to Mary.

b. The ring passed to Mary.

The structure of (14a)-(14b) is shown in (15).

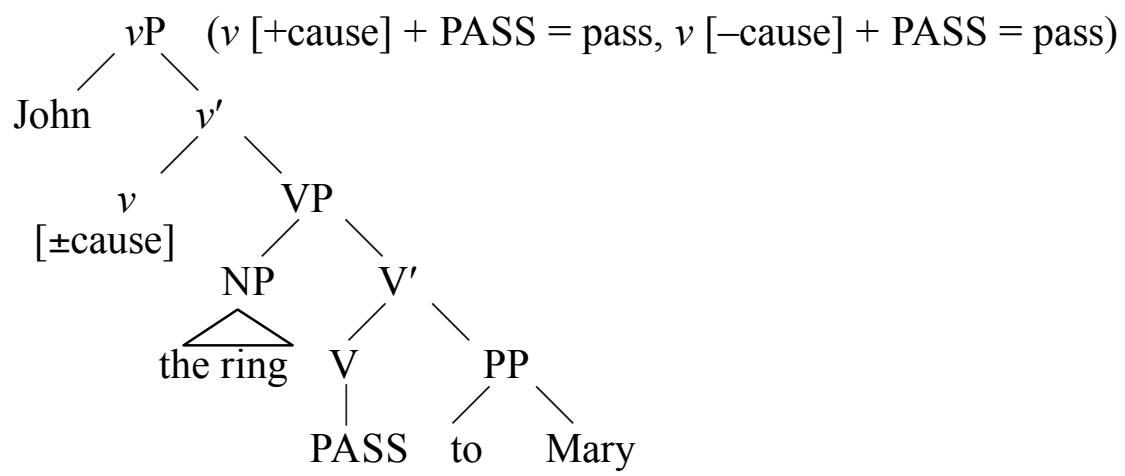


Exactly as in (11), there are two verbs in the structure of (14a) as illustrated in (15): the small $v$ and the capital PASS. The higher verb, small $v$, assigns the agent role to John. The small $v$-projection expresses the CAUSE of the event, whereas the lower V-projection expresses the resulting CHANGE OF STATE. Accordingly, the ring GOES or PASSES to Mary. The lower verb, capital PASS, is raised to the small $v$-position, and the small $v+$ capital PASS yield the lexical item pass. The highest argument, John, assumes the subject position of the sentence.

On the other hand, (14b), the unaccusative counterpart of (14a), has only two arguments, the theme and the goal. The ring is the theme, and Mary is the goal. Since the agent argument is missing, one possibility is that the small $v$-projection is absent and there is only the large V-projection in this case. The highest argument, the ring, is raised to the TP Spec position and becomes the subject of the sentence. An alternative possibility, with similar effects, is that the small $v$ is present but has the feature [-cause]. Unlike the small $v$ with [ + cause], the small $v$ with [-cause] does not assign the agent role to its Spec position. In this case also, the highest argument is the ring because the agent is absent. Hence, the ring becomes the subject of the sentence. Capital PASS is raised to the [-cause] $v$ and they yield the lexical item pass, which is identical to the ditransitive pass in form. Murasugi and Hashimoto (2004) assume the latter analysis because the [-cause] small $v$ shows up overtly in some (di)transitve/unaccusative verb pairs in Japanese, such as $u t u-s-(r) u$ (photograph(transitive)-Pres) / utu-r-(r)u (photograph (unaccusative) -Pres) verb pair.

This analysis elegantly accounts for the two types of causatives known to exist in English and illustrated in (16) and (17):

(16) a. I caused John to go.

b. I made John open the window.

(17) a. I opened the window.

b. I put a pair of shoes on John.

The causative verbs such as 'make,' 'cause,' 'let,' and 'have' express causative meanings by themselves. They form a causative sentence with a sentential complement which has a predicate of its own. This kind of causatives is productive, and is derived by syntactic processes. Therefore, the causatives in (16) are called syntactic causatives. In syntactic causatives, both of a causer and a causee can be agents. Thus, they have a biclausal structure.

On the other hand, the causatives in (17) are called lexical causatives. In (17), the transitive verbs open and put function as causative verbs. The causative meaning and a resultive event are contained in the lexical item itself. In lexical causatives, only a causer like $I$ behaves as an agent. Therefore, they have a mono-clausal structure. The structure of (16b) and (17a) are shown in (18) and (19), respectively.

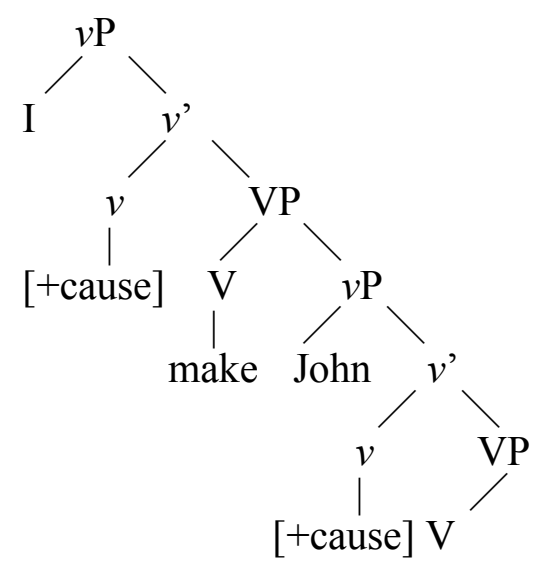


(19)

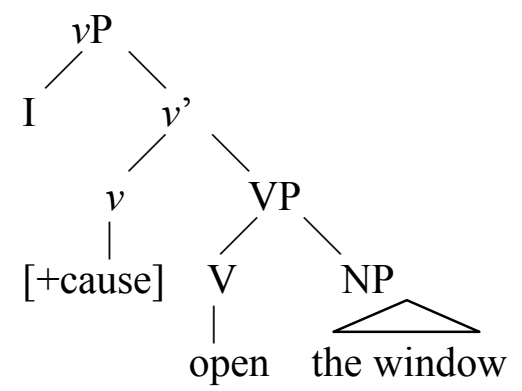

It is said that Japanese also has syntactic causatives and lexical causatives like English. As shown in (20), Japanese morphological -(s)ase causatives are formed by attaching the causative suffix -(s)ase to the verb stems.
a. Taroo ${ }^{-g a} \quad$ Hanakoj-o $_{j}$ /ni hasir-(s)ase-ta.
-Nom -Acc/Dat run-Cause-Past
'Taro made/had Hanako run.'
(intransitive)
$\begin{array}{lllll}\text { b. Taroo-ga } & \text { Hanako-ni } & \text { nimotu-o } & \text { mot-(s)ase-ta. } & \text { (transitive) } \\ \text {-Nom } & \text {-Dat } & \text { luggage-Acc } & \text { carry-Cause-Past } & \end{array}$ 'Taro made/had Hanako carry the luggage.'

These examples show that the causee can be the agent of the "embedded" predicate just as in the case of syntactic causatives in English.

As is the case in English, there are some ditransitive and transitive verbs that function as causative verbs in Japanese. Some of them are listed with their unaccusative counterparts in (21).
(di)transitives
a. mi-se-ru (= show-Pres)
b. utu-s-(r)u (= photograph-Pres)
c. todok-e-ru (= deliver-Pres)
d. os-ie-ru (= teach-Pres)
e. ki-se-ru (= dress-Pres)
f. kasan-e-ru (pile up-Pres)
unaccusatives
mi-ru (= see-Pres)
utu-r-(r)u (= photograph-Pres)
todok-(r)u (=be delivered-Pres)
os-owar-(r)u (= be taught-Pres)
ki-ru (=put on-Pres)
kasan-ar-(r)u (=be piled up-Pres)

These verbs function as causative verbs and form lexical causatives. (22) is a lexical causative sentence with the ditransitive verb kiseru (dress).

(22) Hanako-ga Taroo-ni yoohuku-o ki-se-ru.

-Nom -Dat clothes-Acc dress-Pres

'Hanako puts the clothes on Taro.'

The sentence (22) does not mean 'Taro puts on his clothes,' rather it means 'Hanako puts them on Taro,' or 'Hanako dresses Taro.' Thus, only Hanako is an agent. Taroo is not an agent but behaves as a goal. Thus, the lexical causative in (22) has a mono-clausal structure.

It has also been recognized that Japanese morphological -(s)ase causatives are biclausal. This is supported by the examples in (23a) and (23b).
a. Taroo ${ }^{-g a}$ Hanakoj-ni zibun ${ }_{i} *_{j}$-no koto-o hanasi-ta. -Nom -Dat self-Gen things-Acc tell-Past 'Taro told Hanako (things) about himself.' 


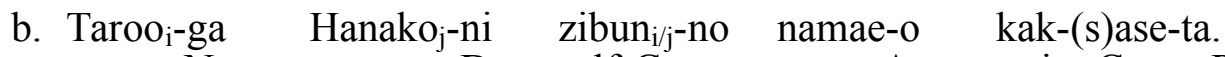
-Nom -Dat self-Gen name-Acc write-Cause-Past

'Taro made/had Hanako write self's (her/his) name.'

(Murasugi and Hashimoto 2004:17)

It is well known that the Japanese reflexive pronoun zibun (self) is subject-oriented (Kuroda, 1965, among others). Thus, in (23a), only Taroo is a subject and zibun can take only Taroo as its antecedent. In (23b), however, zibun can take either Taroo or Hanako as its antecedent. This implies that both Taroo and Hanako function as a subject. Hence, the sentence in (23b) has a biclausal structure.

However, Matsumoto (2000) suggests that when the causative suffix $-(s)$ ase is attached to the verbs as in (24), the sentence is ambiguous.

\begin{tabular}{|c|c|c|c|}
\hline \multicolumn{2}{|c|}{ transitive base verbs } & \multicolumn{2}{|c|}{ causativized verbs } \\
\hline $\operatorname{hak}(-u)$ & $\begin{array}{l}\text { 'put } \ldots \text { on one's } \\
\text { own lower body' }\end{array}$ & hak-ase(-ru) & $\begin{array}{l}\text { 'put ... on someone } \\
\text { else's lower body' }\end{array}$ \\
\hline mato $(-u)$ & $\begin{array}{l}\text { 'put } \ldots \text { on, wrap } \\
\text { oneself in' }\end{array}$ & matow-ase(-ru) & $\begin{array}{l}\text { 'put ... on someone } \\
\text { else, wrap' }\end{array}$ \\
\hline tabe $(-r u)$ & 'eat' & tabe-sase(-ru) & 'make ... eat, feed' \\
\hline$k u(-u)$ & 'eat' (colloquial) & $k u w$-ase(-ru) & 'make ... eat, feed' \\
\hline$n o m(-u)$ & 'drink' & nom-ase(-ru) & 'make ... drink, feed' \\
\hline$s u(-u)$ & 'suck' & suw-ase(-ru) & 'make ... suck, suckle' \\
\hline $\operatorname{shir}(-u)$ & 'come to know' & shir-ase(-ru) & 'let ... know, inform' \\
\hline$k i k(-u)$ & 'hear' & kik-ase(-ru) & 'let ... hear, tell' \\
\hline $\operatorname{mots}(-u)$ & 'come to have' & mot-ase(-ru) & $\begin{array}{l}\text { 'make ... have, put } \\
\text { in the hand of' }\end{array}$ \\
\hline $\operatorname{nigir}(u)$ & 'grasp' & nigir-ase(-ru) & $\begin{array}{l}\text { 'make ... take, put } \\
\text { in the hand of' }\end{array}$ \\
\hline$o(-u)$ & $\begin{array}{l}\text { 'carry ... on one's } \\
\text { back, bear' }\end{array}$ & ow-ase(-ru) & $\begin{array}{l}\text { 'make ... bear, } \\
\text { burden' }\end{array}$ \\
\hline
\end{tabular}

(Matsumoto 2000:144)

(25a) and (25b) are the -(s)ase causatives with the verbs taberu (eat) and kiku (hear/listen).
a. Taroo-ga
Hanako-ni -Nom -Dat bread-Acc
tabe-sase-ta. eat-Cause-Past

'Taro made Hanako eat some bread.'
b. Taroo-ga Hanako-ni ongaku-o kik-(s)ase-ta. -Nom -Dat music-Acc listen-Cause-Past 'Taro made Hanako listen to music.'

The sentences in (25) are ambiguous; Hanako is an agent in one reading, and it is a goal in another reading. The two different readings are shown in (26) and (27).

(26) a. Taro gave an order to Hanako and Hanako ate some bread.

b. Taro fed Hanako with some bread.

(27) a. Taro gave an order to Hanako and Hanako listened to music.

b. Taro played music for Hanako.

In (26a) and (27a) Hanako is interpreted as an agent, but as a goal in (26b) and (27b). 
In addition, Matsumoto (2000) suggests that this ambiguity disappears when the causee is not capable of the caused or permitted actions by himself or herself. Relevant examples are shown in (28).
a. Hahaoya-wa akatyan-ni kutsushita-o hak-ase-ta. mother-Top baby-Dat socks-Acc put on-Cause-Past 'The mother put the socks on the baby's feet.'
b. Hahaoya-wa akatyan-ni miruku-o nom-ase-ta. mother-Top baby-Dat milk-Acc drink-Cause-Past 'The mother fed the baby with milk (in a bottle).'

(Matsumoto 2000: 142)

The interpretation 'the mother gave an order to the baby and the baby put on the socks or drank the milk by himself/herself' is pragmatically unnatural for (28). The only possible readings are the ones indicated by the English translations. In these readings, the causee behaves as a goal. Thus, the sentences have a mono-clausal structure.

The monoclausality of (28a) is supported by the sentence in (29).

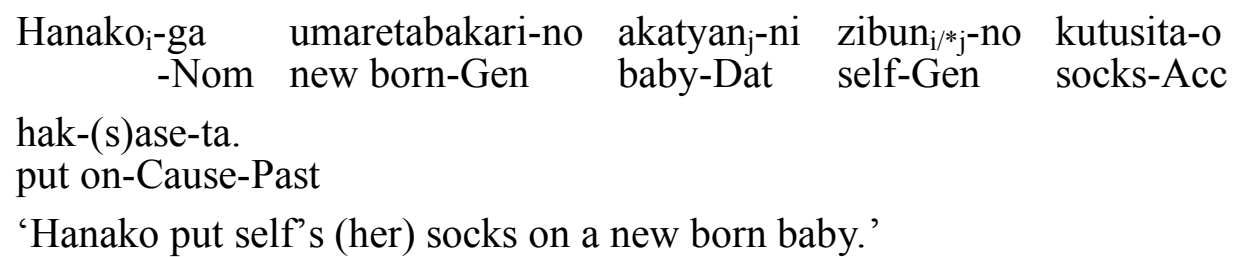

(Murasugi and Hashimoto 2004:18)

As mentioned before, Japanese reflexive pronoun, zibun, is subject-oriented. In (29), it cannot take akatyan (the baby) as its antecedent. This indicates that only Hanako is an agent and (29) is monoclausal. Matsumoto (2000) named these -(s)ase causatives that have a mono-clausal structure "lexical -(s)ase causatives."

Based on Matsumoto's (2000) hypothesis, Murasugi and Hashimoto proposed the structures of these two types of -(s)ase causatives in $v$-VP frame, as illustrated in (30a) and (30b).

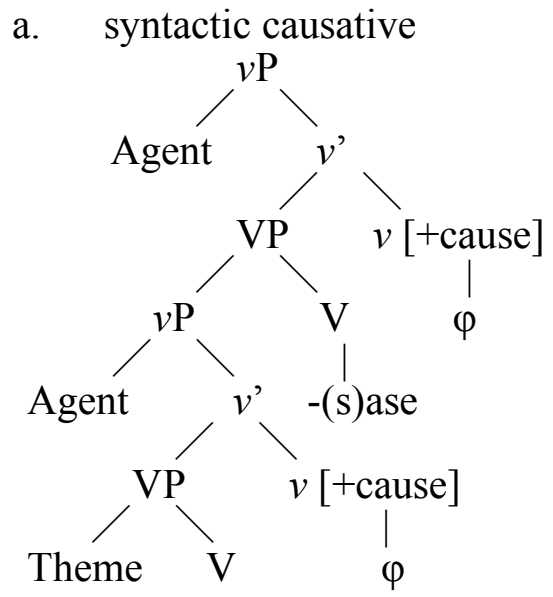

b. lexical -(s)ase causative

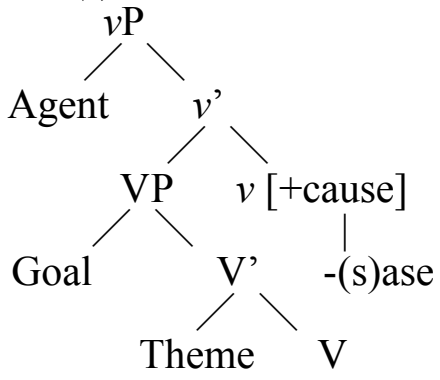

According to this analysis, -(s)ase is ambiguous in the adult grammar of Japanese. When it is an independent large $\mathrm{V}$, it takes a $v$-projection as its complement and yields a complex structure. In this case, the dative argument is interpreted as an agent. In the other case, it combines with a large $\mathrm{V}$ and forms a complex verb to yield a simple sentence with no 
embedding. The dative argument is then interpreted as a goal. In Murasugi and Hashimoto's terms, this means that $-(s)$ ase is a realization of the [+cause] $v$. In the former type of causatives, or the syntactic causatives, as in (30a), since both the causer and the causee function as subjects, an agent role is assigned to the causer by the higher small $v$ and to the causee by the lower small $v$. On the other hand, in the latter type of causatives, or the lexical -(s)ase causative, as shown in (30b), -(s)ase is the realization of [+cause], and a causee functions as a goal. Here, the causee does not appear in the Spec of $v \mathrm{P}$, but it appears in the Spec of $\mathrm{VP}^{3}$.

\subsection{The Analysis of Acquisition Data with $v$-VP Frame}

Murasugi and Hashimoto suggest that there are four steps to acquiring verbs and morphological -(s)ase causatives in Japanese.

(31) Stage I: the small $v$ is tiyu/tita/tite (do/did/doing)

Stage II: the small $v$ is null

Stage III: the acquisition of lexical causatives and transitive verbs; several erroneous lexical realizations of $v$

Stage IV: the acquisition of syntactic causatives; several erroneous lexical realizations of $\mathrm{V}$

According to Murasugi and Hashitmoto, before Stage I, Akkun produced sentences without overt verbs at around the age of 2. Some of the examples are shown in (32a) and (32b).
a. Motto koe buubu $\varphi$
'(I will give) more water to this.'
b. Koe Papa hai doozyo $\varphi$
this Daddy yes please
'This one. (I want give it) to Daddy.'
$(2 ; 0) \quad \varphi=\operatorname{suru}(\mathrm{do})$

$\varphi=\operatorname{ageru}($ give $)$

(Murasugi and Hashimoto 2004:3)

In (32a), ageru (give) is missing. In (32b), Akkun produced hai doozyo. Hai means 'yes' and doozyo means 'please,' but the phrase hai doozyo means 'Here you are.' Murasugi and Hashimoto consider that before Stage I, Akkun initially uses hai doozyo to express the meaning of 'give' or possibly transfer of an item from one person to another. He did not use an actual verb in the ditransitive construction.

At around 2;5, which corresponds to the beginning of Stage I $(2 ; 5-2 ; 9)$, Akkun started to place tiyu/tita/tite 4 in the sentence-final position quite productively. Some of the relevant examples are cited in (33).

\footnotetext{
3 Matsumoto's (2000) analysis is supported by Murasugi, Hashimoto and Kato $(2003,2005)$. They report, based on Murasugi and Hashimoto's longitudinal study with Akkun, that lexical - $(s)$ ase causatives are acquired earlier than syntactic causatives. The same results are obtained in the experimental study conducted by Fuji (2006). Murasugi, Hashimoto and Kato and Fuji's findings of the two stages in acquiring - $(s)$ ase causatives suggest that there are two types of - (s) ase causatives in adult Japanese, syntactic and lexical causatives. This is because they are clearly distinguished and there is no reason to suppose that the later acquisition of syntactic causatives results in the loss of lexical causatives.

4 Tiyu/tita/tite are suru/sita/site in adult speech, and they correspond in meaning to 'do/did/doing' in English. (Murasugi and Hashimoto 2004: 4)
} 
a. Mama Akkun hai doozyo tiyu. $(2 ; 5)$ Mommy yes please do 'Akkun (/I) will give it to Mommy.'

b. Mama Akkun paku tiyu. (2;7) Mommy onomatopoeia do 'Mommy, please make Akkun(/me) eat this.'

c. Akuun nezi kuyukuyu tite, konoko syabeyu. $(2 ; 9)$ screw turn around doing this one talk 'When Akkun (/I) will wind this one around, it will talk.'

(Murasugi and Hashimoto 2004:5)

Note here that tiyu/tita/tite never appeared before Stage I. Murasugi and Hashimoto (2004) observe a number of relevant examples and report that the "predicates" that occur with tiyu/tita/tite are typically onomatopoeic or mimetic expressions. For example, paku in (33b) is the sound that describes a person putting a food into his/her mouth. The utterance means, 'Please, mother put this in Akkun's mouth' or more literally, 'Mother makes this food go into Akkun's mouth.' Kuyukuyu in (33c), which corresponds to kurukuru in adult speech, is a mimetic word describing things turning around. The child tried to say that he would wind the screw, or more literally that he would cause the screw to turn around, and as a result the toy would talk.

Based on the close observation of a child's synchronic change of the verbal forms, Murasugi and Hashimoto (2004) propose that the child at this stage uses tiyu/tita/tite to describe an activity that causes a certain event or change of state. The adult counterpart of tiyu/tita/tite, suru/sita/site, can assign the agent role, like the English verb do/did/doing. The rest of the utterance describes an event or a change of state. Thus, tiyu/tita/tite seems to correspond exactly to the small $v^{5}$. The structure proposed by Murasugi and Hashimoto to the

5 Note here that the hypothesis that tiyu/tita/tite corresponds to the small $v$ can be confirmed by the adult grammar of Malayalam. The -(i) $k k$ suffixation introduces a new argument into the syntactic frame of the verb to which it attaches. (Madhaavan, 2006) According to Madhavan (2006), Malayalam has regular intransitivetransitive pair, and the suffix -(i)kk functions as a transitivizer as in (i).

(i) a. munn-uka / mukk-uka sink $_{\text {intr }}$ inf sink $_{\text {tr }}$ inf b. poTT-uka / poTT-ikk-uka break $_{\text {intr }} \quad$ break $_{\text {tr }}$
(Madhavan 2006:1)

This -(i) $k k$ suffixation also functions as a causativiser.

(ii) kara-y-uka / kara-y-ikk-uka cry make cry
(Madhavan, 2006:1)

However, -(i)kk suffixation is not allowed for loan (foreign) words in Malayalam: cey (do) is used instead of the causative suffix -(i)kk. The relevant examples are shown in (iii).

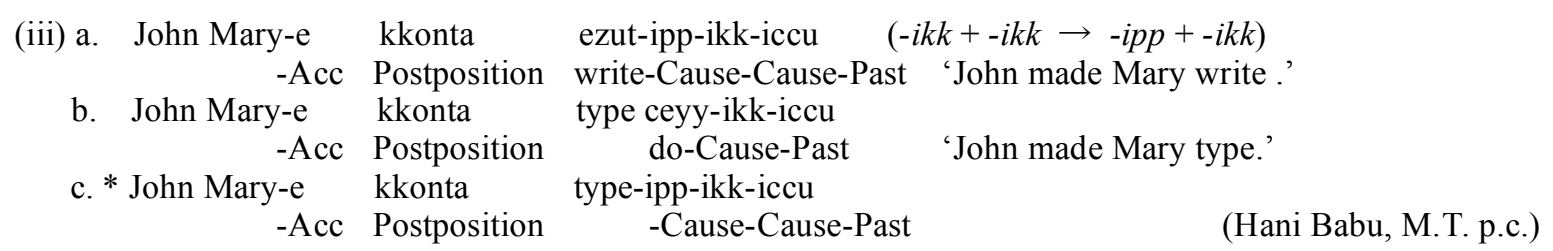

(iiic) is ill-formed since the causative -ikk is attached to the loan word type. Under Murasugi and Hashimoto's $v$-VP Frame analysis, in the adult Malayalam, the small $v$ is realized as $d o$ in forming the causatives of the loan (foreign) words; in Japanese child grammar, at Stage I, the small $v$ is realized as do as well. Thus, the Stage I, where Japanese-speaking children use suru (do) to describe the activity, corresponds to one type of the causative formation of adult Malayalam. Intermediate stages in grammar acquisition is restricted in the possible human grammar. 
sentence (33c) is shown in (34).

(34)

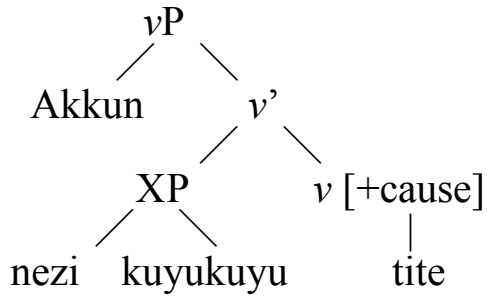

(Murasugi and Hashimoto 2004:5)

In (34), tite describes an activity that causes a screw to turn around, and Akkun is the agent. The complement of the small $v$ is indicated not as VP but as XP because it lacks a verb. Again, kuyukuyu (kurukuru) is a mimetic word describing things turning (around), and the XP expresses the meaning of 'the screw turns.' In this stage, the child utilizes the $v$-VP frame, and the small $v$ is phonetically realized as tiyu/tita/tite.

However, the child, in Stage I is still step away from the adult grammar: the actual lexical items for the $v$-V combination are not acquired. ${ }^{6}$ As for Akkun, the unaccusative verbs and ditransitive verbs have been acquired at around $2 ; 9$, which we call Stage II $(2 ; 9-4 ; 8)$. The sentences in (35) are examples of correct usage of these verbs.
(35) a. dango-ga uta pakan tite, dango-ga atta. (2;9) dumpling-Nom lid onomatopoeia doing dumpling-Nom there-be 'There was a dumpling (when I) opened the lid of the dumpling (box).'

b. Mama tyotto ageyu.

Mommy a little give

'Mommy, (I will) give you a little bit.'

(Murasugi and Hashimoto 2004:6)

In (35a), an unaccusative verb atta appears, and in (35b), a ditransitive verb is used correctly.

In Stage II, however, the child also makes some interesting errors. Akkun, for example, often uses unaccusative verbs for transitive or ditransitive verbs. Some of the relevant examples are cited in (36).

$$
\begin{aligned}
& \text { (36) a. Koe ziityan ni miyu. } \\
& \text { this Grandfather to see } \\
& \text { 'I show this to Grandfather.' }
\end{aligned}
$$

b. Kore, ai-toku kara saa. this open(unaccusative)-keep as Int. '(I will) open this and keep it open.'

c. Todok-ok-ka, ano hito ni todok-(y)oo todok-(y)oo. arrive-let's that person to arrive-let's arrive-let's 'Let's send (it). Let's send (it) to that person.'

(Murasugi and Hashimoto 2004:10)

In (36a), although a ditransitive verb, miseru (show) must be used in this context, Akkun produces an unaccusative verb, miyu ${ }^{7}$ (see), "by mistake." The same error can be found in (36b). Akkun uses the unaccusative verb aku (be open), instead of the transitive verb akeru (open). In (36c), the transitive form todokeru (deliver something) would be used by adults,

\footnotetext{
${ }^{6}$ In English, for example, as was illustrated in (13) and (14), the [+cause] small $v$ plus capital PASS is realized as pass, and so is the [-cause] small $v$ plus capital PASS.

${ }^{7}$ Miyu is miru in adult usage.
} 
but Akkun uses an unaccusative form todoku (be delivered) instead. This kind of error has been observed in the previous literature we surveyed in the first section of this article.

Murasugi and Hashimoto propose that children produce these errors because they assume [ \pm cause] $v$ to be zero. The sentences in (37) show verb pairs of transitive and unaccusative in adult grammar. (37a) and (37b) have the representations in (38a) and (38b) respectively.
(37) a. Hanako-ga hon-o Taroo-ni todok-e-ru. (ditransitive)
-Nom book-Acc -Dat deliver-Pres 'Hanako delivers a book to Taroo.'
b. Hon -ga Taroo-ni todok- $\varphi-(r) u$. book-Nom -Dat be delivered-Pres
'A book is delivered to Taroo.'

(Murasugi and Hashimoto 2004:8)

(38) a.

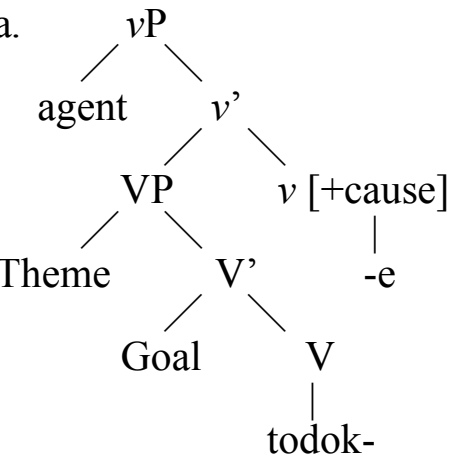

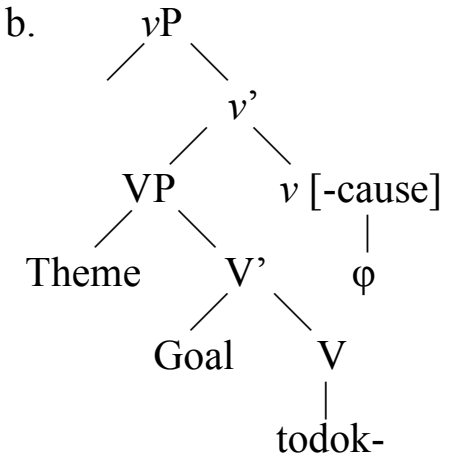

(Murasugi and Hashimoto 2004:8-9)

In (38a), $v$ is realized as $-e$, but in $(38 \mathrm{~b})$, [-cause] $v$ is not realized phonetically.

Now, let us consider the sentence in (36a). (39) is the adult counterpart of (36a).

(39) Kore ziityan ni miseru.

this Grandfather to show

'I show this to Grandfather.'

In (39), the ditransitive verb, miseru (show) is used. The structure of the adult-grammar form in (39) is illustrated in (40).

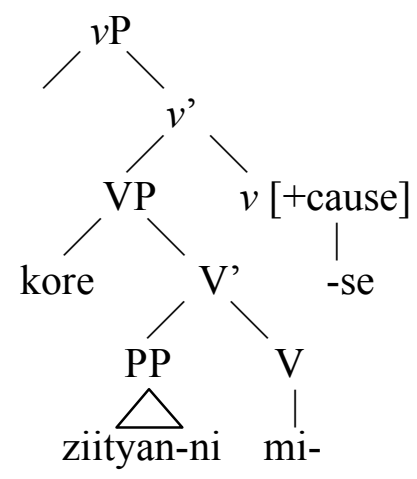

However, if Akkun hypothesized that $[ \pm$ cause $] v$ was zero, the structure which Akkun had in his mind would have been as in (41) instead. 
(41)

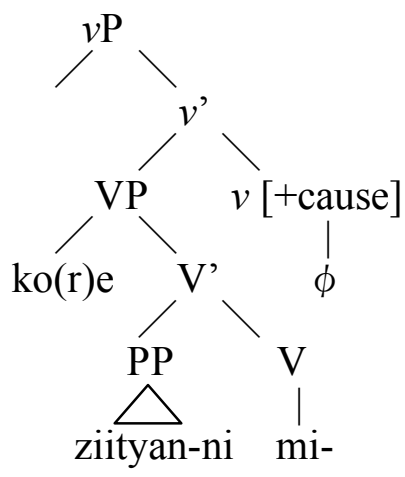

In (41), the small $v$ is not realized phonetically. Thus, Akkun produces the unaccusative verb miyu instead of the ditransitive verb miseru. Akkun optionally used unaccusatives for (di)transitives, but never vice versa, and Murasugi and Hashimoto observed this type of errors for two years, up to $4 ; 8 .{ }^{8}$

More generally, the Japanese-speaking children start out with the VP, representing STATE or CHANGE OF STATE. Then, they embed this under [ \pm cause] small $v$ 's, but initially assume that [ \pm cause] small $v$ 's are always a zero morpheme, as in English.

During Stage II, Akkun produced lexical causative sentences without the causative suffix $-(s)$ ase as in (42).
(42) a. Mama Akkun non-de. Mommy drink-Request
'Mommy, please feed me (with milk).'
b. Mama-ga pantyu nui-da toki.
Mommy-Nom underpants undress-Past when
Literal meaning: ... when Mommy took her underpants off.
Intended meaning: ... when Mommy took my underpants off me.

(Murasugi and Hashimoto 2004:14)

He consistently omitted the causative morpheme -(s)ase and only used the regular verbs. For example, in (42a), the causative form nom-ase-te should be used in this context, but Akkun omits -(s)ase and produces non-de instead. He intends to say 'Mommy, please feed me,' but the meaning of what he actually says is 'Mommy, drink Akkun.' Similarly, in (42b), the causative form nug-ase-ta should be used in this context, but Akkun omits -(s)ase and produces $n u i$-da instead. He intends to say '(I hurt) when Mommy undressed my underwear,' but what he actually says was '(I hurt) when Mommy took off her underwear.'

Sentences with the causative suffix, $-(s)$ ase, are observed at around the age of late 3;5 or 3;6. We term this stage as Stage III. A couple of relevant examples are shown in (43).

$$
\begin{gathered}
\text { (43) a. Akkun-ni tabe-sase-tee. } \\
\text {-Dat } \\
\text { eat-Cause-Request } \\
\text { 'Please feed Akkun (/me) (with food).' }
\end{gathered}
$$

\footnotetext{
${ }^{8}$ The "mistake" is related to the alternation in (15), which is widely attested. There are (di)transitiveunaccusative pairs in English, e.g., 'John sank the boat/the boat sank' with the verb sink. Both lexical items in the alternation have the same surface forms. In Murasugi and Hashimoto' (2004) analysis, both the [+cause] and the [-cause] small $v$ 's are realized as zero-morphemes (i.e., without the phonological content). Hence, we can say that Japanese-sepaking children at Stage II assume that Japanese verbs are composed just like their English counterparts.
} 
b. Nomi-tyatye-te. (-tyatye seems to correspond to the adult -sase) drink-Cause-Request.

'Please feed me (with miso soup.)'

(43) can be considered a lexical -(s)ase causative. If (43a), for example, is the syntactic causative, the meaning of the sentence should be something like 'You will permit me to eat some food, please,' but (43a) does not have such a meaning. Instead, the meaning of (43a) is 'You feed some food to me,' and with this interpretation, Akkun is a goal. Therefore, (43a) is the lexical $-(s)$ ase causative, where $-(s)$ ase is a realization of [+cause] $v$. The same argument applies for (43b).

The syntactic causatives were observed at around the age of 5. An example is shown in (44).

(44) Obaatyan-no toko de tabe-masu
Grandma-Gen
$\begin{aligned} & \text { place at eat-Pres (formal) } \\ & \text { Int beer }\end{aligned}$
please
'(I will) eat (dinner) at Grandma's place. Eh, allow me to drink beer (here),
please.'
(Murasugi and Hashimoto 2004:15)

In (44), Akkun does not ask his mother to feed him, but asks her to let him drink beer. Thus, although the causee Akkun is not overtly produced, it is agentive. Hence, the causative in (44) is considered to be a syntactic causative.

Recall here the errors of unaccusative and transitive pairs in (36). These errors and the causative sentences without -(s)ase were observed during the same period. Therefore, Murasugi and Hashimoto propose that Akkun produces sentences like (42) because [ + cause] $v$ was not phonetically realized. In lexical -(s)ase causatives, -(s)ase appears in the head of $v \mathrm{P}$, but the small $v$ is assumed to be zero. Hence, Akkun omitted -(s)ase and produced (42). When he starts to produce transitive and ditransitive verbs and lexical -(s)ase causatives correctly, he starts to realize the small $v$ with an overt morpheme. However, syntactic causatives are acquired later because -(s)ase appears in the head of VP in this construction. The late acquisition of Japanese syntactic causatives could be due to by the complex (or "embedded") structure and the variety of the lexical realization of the small $v$ in the language.

\section{Further Support for $v$-VP Hypothesis from Sumihare's Data}

In the previous section, we discussed Murasugi and Hashimoto's $v$-VP frame analyses for the erroneous verb forms observed in Japanese first-language acquisition. In this section, we will provide additional evidence for this analysis. We will show that exactly the same acquisition process can be found with another Japanese-speaking child, Sumihare (Noji, 1974-1977).

The overextensions of transitive/intransitive verb pairs in Japanese child language are also reported by Morikawa (1997). She analyzes the data of Sumihare in the CHILDES, and reports that he erroneously used the intransitive form instead of the transitive form as in (45a).

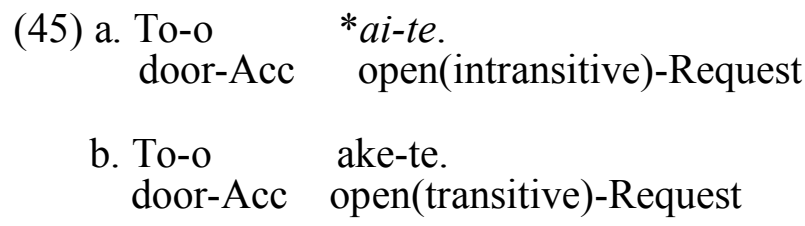


Sumihare asked his parents to open the door. While he should have employed the transitive verb akeru (open) as in (45b), the intransitive verb aku (be open) was used instead as in (45a). This type of error can be categorized as the same type of error as those.

Unlike Murasugi and Hashimoto, however, Morikawa (1997) reports that Sumihare overextended transitive verbs as well. Table 1 shows the frequencies of the overextensions of transitive/intransitive verbs. ('Vi' $=$ intransitive verbs and ' $\mathrm{Vt}$ ' $=$ transitive verbs.) From 1;11 through 2;1, Sumihare used many verbs correctly. He, however, overextended intransitive verbs for transitive verbs for thirteen times and he overextended transitive verbs for intransitive verbs for 8 times. The number of total overextensions is given in the section of Subtotal.

Morikawa (1997) analyzes 41 overextensions of intransitive and transitive verbs, focusing on the productivity of target verbs. The results are summarized in Table 2.

"Productive target" refers to the verbs for which Sumihare had already acquired the correct form. For example, as for ageru, he incorrectly produces the unaccusative verb agaru (ascend) instead of the transitive verb ageru (raise) at 3;1. At that time, however, Sumihare produces the verb ageru correctly in different situations. In contrast, 'unproductive target' refers to the verbs for which Sumihare had not acquired the correct form. Thus, when he incorrectly uses the unaccusative verbs with the transitive meaning at $2 ; 2$, the correct form of the transitive verb ageru was never found in his production.

Table 1. Frequencies of overgeneralizations and correct uses of verbs form transitive/intransitive verb pairs

\begin{tabular}{|c|c|c|c|c|c|c|}
\hline \multirow[b]{2}{*}{ Age level } & \multicolumn{3}{|c|}{ Overextensions } & \multirow{2}{*}{$\begin{array}{c}\text { Correct } \\
\text { uses }\end{array}$} & \multirow{2}{*}{$\begin{array}{l}\text { Total } \\
\text { uses }\end{array}$} & \\
\hline & $\mathrm{Vi}$ & $\mathrm{Vt}$ & Subtotal & & & \\
\hline $1 ; 11-2 ; 1$ & 13 & 8 & $21(6.3 \%)$ & 313 & 334 & \\
\hline $2 ; 2-2 ; 4$ & 10 & 0 & $10(1.1 \%)$ & 883 & 893 & \\
\hline $2 ; 5-2 ; 7$ & 2 & 1 & $3(0.4 \%)$ & 681 & 684 & \\
\hline $2 ; 8-2 ; 10$ & 1 & 0 & $1(0.1 \%)$ & 544 & 545 & \\
\hline $2 ; 11-3 ; 1$ & 4 & 1 & $5(1.1 \%)$ & 455 & 460 & \\
\hline $3 ; 2-3 ; 3$ & 0 & 1 & $1(0.2 \%)$ & 406 & 407 & \\
\hline Total: & 30 & 11 & $41(1.2 \%)$ & 3,282 & 3,323 & (Morikawa 1997:83) \\
\hline
\end{tabular}


Table 2. Productivity of target verbs in extension errors within transitive/intransitive verb pairs

\begin{tabular}{lclc}
\hline \multicolumn{2}{c}{ Productive target } & \multicolumn{2}{c}{ Unproductive target } \\
ageru 'raise' & $3 ; 1$ & agaru 'ascend' & $1 ; 11$ \\
aku 'open' & $2 ; 1$ & ageru 'raise' & $2 ; 2$ \\
deru 'go out' & $2 ; 6$ & akeru 'open' & $2 ; 0$ \\
& $3 ; 2$ & & $2 ; 1$ \\
okosu 'wake X up' $3 ; 1$ & dasu 'take out' & $2 ; 0$ \\
simeru 'close' & $2 ; 10$ & hazimaru 'begin' & $3 ; 0$ \\
toru 'take, get' & $2 ; 3$ & hikkomeru 'take X in' & $2 ; 11$ \\
& & katamaru 'coagulate' & $2 ; 1$ \\
& & kuttuku 'adhere' & $2 ; 5$ \\
& & naosu 'fix' & $2 ; 5$ \\
& & naraberu 'arrange in a row' & $2 ; 11$ \\
& & nigasu 'release' & $2 ; 4$ \\
& & nokeru 'remove' & $2 ; 2$ \\
& & noseru 'mount' & $2 ; 2$ \\
& & nukeru 'come off' & $2 ; 1$ \\
& & nurasu 'wet' & $2 ; 2$ \\
& & okosu 'wake X up' & $1 ; 11$ \\
& & &
\end{tabular}

Total: 6 types / 11 tokens

Total: 18 types / 30 tokens

(Morikawa 1997:85)

The present study analyzes Sumihare's production data ${ }^{9}$ in light of Murasugi and Hashimoto's (2004) $v$-VP hypothesis, and reports that the erroneous causative forms without the causative suffix - $(s)$ ase were also produced by Sumihare just at the time when he made the overextensions of transitive/intransitive verb pairs. That is, Sumihare went through exactly the same acquisition stages as Akkun ${ }^{10}$.

At one year of age, as in (46), Sumihare produces sentences without overt verbs.
(46) a. Ta-ta
$\varphi$
$(1 ; 7)$
$\varphi=$ hak-ase-te (put on me)
'Please put my socks on me.'
b. Kaatyan hai $\varphi(1 ; 9) \quad \varphi=$ age-ru (give)
Mommy yes
'Mommy (I) will give you.'

9 We found some errors in CHILDES database of Sumihare, e.g., some data are duplicated, some parts in Noji (1974-1977) are not typed in the database, and there are some typological errors. Hence, the present paper makes the analysis based on the original data published by Noji (1974-1977).

10 There are some individual differences between Akkun and Sumihare, but acquisition order is the same. The age of each stage can be summarized as in (i) and (ii).

(i) Akkun

Stage I: $(2 ; 5)-(2 ; 9)$

Stage II: $(2 ; 9)-(4 ; 8)$

Stage III: $(3 ; 6-)$

Stage IV: (5;3-) (ii) Sumihare

Stage I: $(1 ; 11)-(2 ; 1)$

Stage II: $(2 ; 1)-(2 ; 5)$

Stage III: $(2 ; 5-)$

Stage IV: $(3 ; 4-)$ 
In (46a), the causative form of hak-(r)u (put on), that is, hak-(s)ase-te is missing. In (46b), though the subject is dropped, the indirect object Kaatyan (Mommy) is uttered. Thus, it can be conjectured that a ditransitive verb, age-ru (give), is missing here.

Sumihare's Stage I starts at around 1;11, 6 months earlier than Akkun's. Sumihare starts to put tiyu/tita/tite (suru/sita/site) in the sentence-final position just as Akkun does. In Sumihare's utterances, tiyu/tita/tite is tyuru/sita/site. Relevant examples are shown in (47).
(47) a. Taabi pai tabi throw (onomatopoeia) do-Past
si-ta. 'I took off (a pair of) tabi.'
b. Tootyan, zityan-ga dondon si-ta yo. $(1 ; 11)$ Daddy a man-Nom beat (onomatopoeia) do-Past Int 'Daddy, a man beat (a wall).'
c. Kaatyan ombu tyur-u yo. Mommy piggyback do Int 'Mommy, (I will) give you a piggyback.'

In (47a) and (47b), sita (did) is attached to the end of the sentences, and in (47c), tyuru (do) is attached to the end of the sentence. As can be seen from the data, two children showed exactly the same process. The frequencies of suru-forms are illustrated in Table 3.

It is at 1;11 when suru (tyuru, or 'do') appears in Sumihare's production; at this point, for almost all the cases, sita form is used. At 2;0, however, the conjugation of suru (tyuru) appears. Suru (tyuru)-forms can be considered to be one of the main "verbal" forms a child uses at this stage. The frequent use of suru-forms at around the age of two, given the $v$-VP frame, indicates that the children at this stage acquire the $v$-VP frame, and they realize the small $v$ as suru/sita/site.

In Stage II, from around 2;1 through 2;5, while Sumihare uses verbs correctly, he overextends unaccusative verbs as Morikawa (1997:83) reports. Some examples of his correct use of verbs are given in (48).

$$
\begin{aligned}
& \text { (48) a. Buu toot-ta ne. } \\
& \text { car pass-Past Int. } \\
& \text { 'A car passed.' } \\
& \text { b. Boku tete ara-u. } \\
& \text { I hands wash } \\
& \text { 'I wash my hands' } \\
& \text { c. Teruki-tyan, wa-ga deki-tara age-ru ne. } \\
& \text { ring-Nom finish-after give Int. } \\
& \text { 'Teruki, (I will) give (it) to you, after I finish making a ring.' }
\end{aligned}
$$

In (48a) and (48b), unaccusative and transitive verbs are used correctly. A ditransitive verb is also used correctly employed in (48c). 
Table 3. Frequencies of suru(tyuru)/sita(tita)/site(tite)/siyoo(tyo)/see(tye) (do, did, doing, let's do, do(imperative) respectively) in the sentence final position at Stage I

\begin{tabular}{|c|c|c|c|c|c|c|c|c|c|c|c|}
\hline \multirow{3}{*}{ Age } & \multicolumn{10}{|c|}{ Total Use of suuru/sita/site/siyoo/see (tyuru/tita/tite/tyo/tye) } & \multirow{3}{*}{ Total Use of Verbs } \\
\hline & \multicolumn{5}{|c|}{ Transitives } & \multicolumn{5}{|c|}{ unaccusatives } & \\
\hline & suru & sita & site & siyoo & see & suru & sita & site & siyoo & see & \\
\hline \multirow{3}{*}{$1 ; 11$} & \multicolumn{10}{|c|}{$38(27.3 \%)$} & \multirow{3}{*}{139} \\
\hline & & & 16 & & & & & 22 & & & \\
\hline & 1 & 14 & 0 & 0 & 1 & 1 & 19 & 0 & 2 & 0 & \\
\hline \multirow{3}{*}{$2 ; 00$} & \multicolumn{10}{|c|}{$70(34.7 \%)$} & \multirow{3}{*}{202} \\
\hline & & & 40 & & & & & 30 & & & \\
\hline & 22 & 8 & 7 & 2 & 1 & 12 & 16 & 1 & 0 & 1 & \\
\hline \multirow{3}{*}{$2 ; 01$} & \multicolumn{10}{|c|}{$144(16.3 \%)$} & \multirow{3}{*}{880} \\
\hline & & & 99 & & & & & 45 & & & \\
\hline & 52 & 19 & 15 & 8 & 5 & 14 & 17 & 4 & 5 & 5 & \\
\hline \multirow{3}{*}{ Total } & \multicolumn{10}{|c|}{$252(20.6 \%)$} & \multirow{3}{*}{1,221} \\
\hline & & & 15 & & & & & 97 & & & \\
\hline & 75 & 41 & 22 & 10 & 7 & 27 & 52 & 5 & 7 & 6 & \\
\hline
\end{tabular}

However, at the same time, he erroneously uses unaccusatives for transitives as shown in (49).

(49) a. Kaatyan a-ite. mother be open-Request

Literal meaning: '(Please) be open, mother.'

Intended meaning: '(Please) open (the door), mother.'

b. Koko oite tyame-ru. here put get cold

Literal meaning: 'I put (a cup of tea) here and it gets cold.' Intended meaning: 'I put (a cup of tea) here and make it cold.'

c. Kaatyan taitai aga-tte. Boku-no aga-tte. Mommy a carp streamer go up-Request I-Gen go up-Request aga-tte ya. go up-Request Int

Literal meaning: 'Mommy, please go up my carp streamer. Go up mine. Go up.' Intended meaning: 'Mommy, please make my carp streamer go up higher. Make it higher. Higher.'

In (49a), the adult would use the transitive verb ake-ru, but Sumihare uses an unaccusative verb $a k-(r) u$. In (49b), although a transitive verb samas-(r)u must be used in this context, he uses the unaccusative verb tyame-r $u^{11}$. The same type of error can be observed in $(49 \mathrm{c})$ as well: he uses the unaccusative verb agar- $u$ in the context where a transitive verb age-ru should be used. Thus, not only Akkun but also Sumihare uses unaccusatives for transitives.

Moreover, as mentioned above, Sumihare also uses transitives for unaccusatives. Examples are shown in (50).

\footnotetext{
11 In Japanese, a number of syntactic phenomena, e.g., passives, causatives, honorific sentences, and so on, involve the lexical small $v$, and children have to "learn" the exact lexical realization for each small $v$. Tyameru is the child speech of sameru (things become cold).
} 
(50) a. $N u$ - $i$-ta koko. $\quad(2 ; 1)$
pull-PAST here
Literal meaning: 'I pulled (this) here.'
Intended meaning: '(This) is out from here.'

$\begin{array}{lll}\text { b. SUM: } & \text { Ak-en } \\ \text { open-not } & \begin{array}{l}\text { ak-en. } \\ \text { open-not }\end{array} & (2 ; 1) \quad \text { (transitive) }\end{array}$

Literal meaning: '(I) don't open it. (I) don't open it.'

Intended meaning: '(It) doesn't open. (It) doesn't open.'

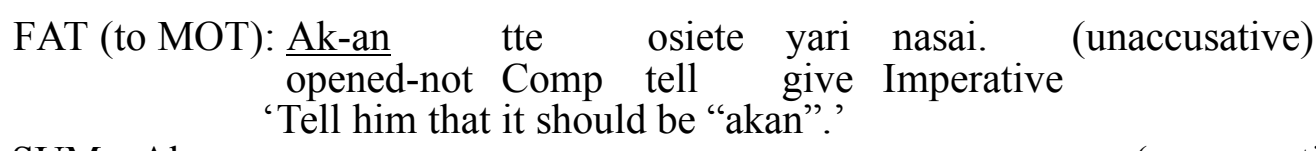

SUM: $\underline{\text { Ak-an. }}$ open-not '(It) doesn't open.'

SUM: Ak-en ak-en ak-en wa ak-en ga. (transitive) open-not open-not open-not Int. open-not Int

Literal meaning: '(I)don't open it. (I) don’t open. (I) don't open it.' Intended meaning: ‘(It) doesn’t open. (It) doesn’t open. (It) doesn't open.'

FAT: Ak-anai yo. open-not Int. 'It doesn't open.'

SUM: Ak-en yo.
Literal meaning: '(I) don't open it.'

(unaccusative)

Intended meaning: '(It) doesn't open.'

(transitive)

In (50a), the past form of the unaccusative verb nuke-ru, nuke-ta, must be used in the adult grammar, but Sumihare used the transitive verb nuk-(r)u. (50b) is an example where the direct evidence does not work in the course of language acquisition. In this particular case, Sumihare couldn't open the door. Hence, the intended meaning is "The door does not open," and the unaccusative verb ak-an ((It) does not open) should be employed. Although he was able to parrot his father's direct correction once, he kept producing the transitive form ak-en ((I) don't open it) for the unaccusative form ak-an. Compare this example with (49a). In (49a), the unaccusative verb $a k-u$ is used erroneously for the transitive form ake-ru. In (50c), on the other hand, the transitive form is overextended. These examples indicate that overextension of unaccusatives and transitives cannot always be one way: Children use the transitive forms for the unaccusative forms as well.

Note here that this type of error was not observed in Murasugi and Hashimoto's (2004) study. The errors that Akkun produced were always in one direction, unaccusatives for (di)transitives. Then, it could then appear that evidence from utterances as in (50a) and (50b) contradict their analysis. However, these errors are in fact compatible with it.

Examples (51a) and (51b) are verb pairs of transitive and unaccusative in adult grammar, and their structures are illustrated in (52a) and (52b) respectively.

$$
\begin{array}{ccc}
\text { (51) a. Taroo-ga Hanako-o } & \text { syasin ni } \begin{array}{l}
\text { utu-s-(r)u. } \\
\text {-Nom photograph-Pres. }
\end{array} & \text { (transitive) } \\
\text { 'Taro takes a picture of Hanako.' } & & \\
\text { b. Hanako-ga syasin ni utu-r-(r)u. } & \text { (unaccusative) } \\
\text {-Nom picture in photograph-Pres. } &
\end{array}
$$

(Murasugi and Hashimoto 2004:7) 
(52) a.

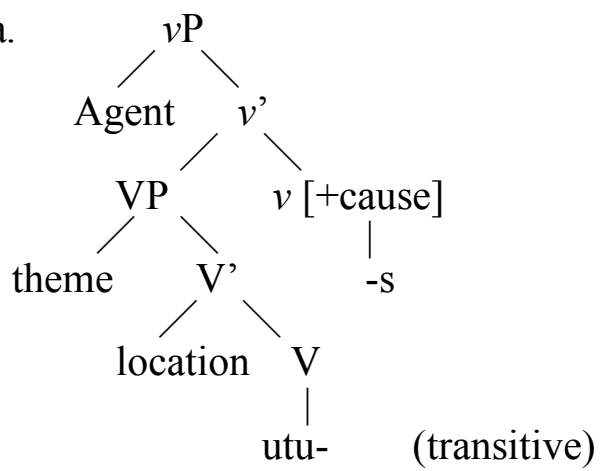

b.

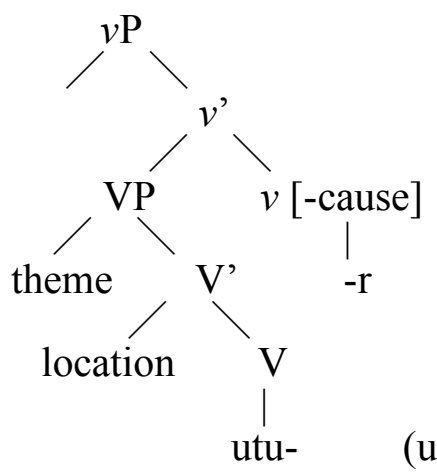

(unaccusative)

Provided that a child assumes [ \pm cause] $v$ to be zero, the structures that $\mathrm{s} /$ he has in mind to represent the sentences in (51a) and (51b) would be those shown in (53a) and (53b).

(53) a.

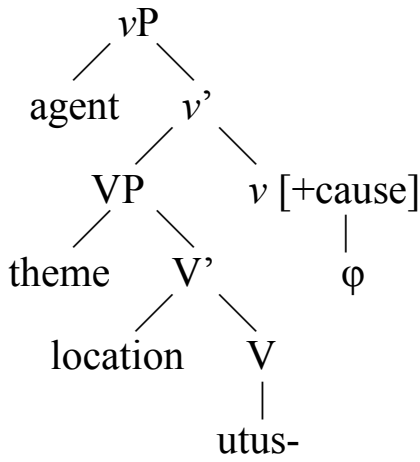

b.

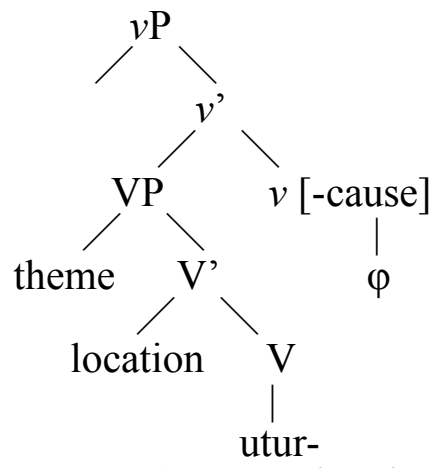

(Murasugi and Hashimoto 2004:8)

Since both [+cause] $v$ and [-cause] $v$ are not phonetically realized, a child does not distinguish (53a) from (53b). However, s/he probably notices that either $-s$ or $-r$ should be attached to the verb, because a verb without these morphemes is never heard. Thus, the child regards utus or utur as V. Then, two logical possibilities are attested by Sumihare's "mistakes." 12 Therefore, errors of unaccusatives and transitives should not always be in one direction. The fact that errors occur in both directions actually supports the hypothesis that [-cause] $v$ is zero.

Hence, not only the errors in (49), but also those in (50) indicate that Sumihare went through Stage II at around 2;0, where he also assumed [ \pm cause] $v$ to be zero. Although Murasugi and Hashimoto's analysis was based on Akkun's errors of using unaccusatives for transitives, the fact that Sumihare overextended transitives as well as unaccusatives gives another piece of strong evidence for their $v$-VP frame analysis. ${ }^{13}$

In this stage, or at Stage II, as in the case of Akkun, causatives without the suffix - $(s)$ ase were also found in Sumihare's production. An example is shown in (54).

(54) Kutyu ha-ite. $\quad(2 ; 1)$

a pair of shoes put on-Request

Literal meaning: '(Please) put on (your) pair of shoes.'

Intended meaning: '(Please) put a pair of shoes on me.'

\footnotetext{
12 Table 1 shows that unaccusative forms tend to be overextended more than transitive forms are. This is also confirmed by Fuji (2006).

13 Morikawa (1997) provides different explanation for these data. She points out that Sumihare's overextension is not frequent (41 out of 3,323 cases involve overextension). She argues that the overextension reflects the stages when the child has not acquired the correct form. This conclusion is based in part on the fact that $2 / 3$ of overextension produced by Sumihare occurred with unproductive target as shown in Table 2 .
} 
In the context of (54), the causative form hak-(s)ase-te should be used. However, Sumihare omits the causative suffix -(s)ase, and produces ha-ite. Thus, we believe that (54) presents additional evidence for $v$-VP hypothesis: a child hypothesizes that the suffix -(s)ase appears in the head of $v \mathrm{P}$, but the child omits it since [ \pm cause] $v$ is assumed to be zero at Stage II. This stage starts at 2;1 and the productive "overextension" lasts until around 2;3.

Table 4 shows the frequencies of Sumihare's overextended verbs, correct verbs (transitive verbs (Vt) and intransitive verbs (Vi)), the use of suru/sita/site, causatives without the suffix $-(s)$ ase, and the correct use of lexical and syntactic causatives at Stage I $(1 ; 11-2 ; 1)$ and Stage II $(2 ; 1-2 ; 5)$. At $2 ; 0$, almost all the verbs have unaccusative forms; mi-te ('see') for mi-sete ('show'), and a-ite ('is open') for ak-ete ('open'), for example, are used. At 2;1 and 2;2, Sumihare overextended quite a few transitives as well as unaccusatives as in (49) and (50), but the overextension decreased after 2;3.The causatives without $-(s)$ ase is also observed in Stage II as in the case of Akkun.

As for Sumihare, 2;5 is a turning point. The verbal errors and the causatives without suffix disappear then; while the correct forms of lexical causatives appear. It is around this time when children start lexically realizing -(s)ase as the small $v$ in the $v$-VP structure.

Sumihare produced the correct forms of lexical causatives productively after around 2;5. Some examples of his Stage III are shown in (55) (see also Table 5).

(55) a. Seizi-kun boku-ga ne nak-asi-tan janaino yo.

I -Nom Int cry-Cause-Past not Int

'It is not me who made Seiji cry.'

b. Okaatyan hak-asi-te. $\quad(3 ; 0)$

Mommy put on-Cause-Request

'Mommy (please) put (a pair of shoes) on me.'

c. Okaatyan kore Terukityan-ga sin-asi-tan yo.

Mommy this -Nom die-Cause-Past Int

'Mommy, Terukityan made this die.'

Table 4. Frequencies of the erroneous and correct verbal forms at Stage I and Stage II

\begin{tabular}{|c|c|c|c|c|c|c|c|c|}
\hline \multirow{2}{*}{ Age } & \multicolumn{2}{|c|}{$\begin{array}{l}\text { Overextension } \\
\text { (Errors) }\end{array}$} & \multirow{2}{*}{$\begin{array}{l}\text { Correct Use } \\
\text { of Vt and Vi }\end{array}$} & \multirow{2}{*}{ 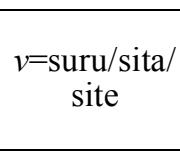 } & \multirow{2}{*}{$\begin{array}{c}\text { Causatives } \\
\text { without } \\
\text { suffix-(s)ase } \\
v=\varphi\end{array}$} & \multirow{2}{*}{$\begin{array}{c}\text { Lexical } \\
\text { Causatives }\end{array}$} & \multirow{2}{*}{$\begin{array}{l}\text { Syntactic } \\
\text { Causatives }\end{array}$} & \multirow{2}{*}{$\begin{array}{l}\text { Total Use } \\
\text { of Verbs }\end{array}$} \\
\hline & Vi & $\mathrm{Vt}$ & & & & & & \\
\hline $1 ; 11$ & $\begin{array}{c}2 \\
(1.5 \%) \\
\end{array}$ & 0 & $\begin{array}{c}99 \\
(71.2 \%) \\
\end{array}$ & $\begin{array}{c}38 \\
(27.3 \%) \\
(27 \%\end{array}$ & 0 & 0 & 0 & 139 \\
\hline $2 ; 00$ & $\begin{array}{c}6 \\
(2.9 \%)\end{array}$ & 0 & $\begin{array}{c}126 \\
(62.4 \%)\end{array}$ & $\begin{array}{c}70 \\
(34.7 \%)\end{array}$ & 0 & 0 & 0 & 202 \\
\hline $2 ; 1$ & $\begin{array}{c}11 \\
(1.3 \%)\end{array}$ & $\begin{array}{c}11 \\
(1.3 \%) \\
\end{array}$ & $\begin{array}{c}713 \\
(81.0 \%)\end{array}$ & $\begin{array}{c}144 \\
(16.3 \%)\end{array}$ & $\begin{array}{c}1 \\
(0.1 \%)\end{array}$ & 0 & 0 & 880 \\
\hline $2 ; 2$ & $\begin{array}{c}10 \\
(0.47 \%) \\
\end{array}$ & $\begin{array}{c}1 \\
(0.045 \%)\end{array}$ & $\begin{array}{c}1,832 \\
(86.54 \%)\end{array}$ & $\begin{array}{c}269 \\
(12.71 \%)\end{array}$ & $\begin{array}{c}3 \\
(0.14 \%) \\
\end{array}$ & $\begin{array}{c}2 \\
(0.09 \%) \\
\end{array}$ & 0 & 2,117 \\
\hline $2 ; 3$ & $\begin{array}{c}3 \\
(0.3 \%)\end{array}$ & 0 & $\begin{array}{c}988 \\
(91.9 \%)\end{array}$ & $\begin{array}{c}82 \\
(7.6 \%)\end{array}$ & $\begin{array}{c}1 \\
(0.1 \%)\end{array}$ & $\begin{array}{c}1 \\
(0.1 \%)\end{array}$ & 0 & 1075 \\
\hline $2 ; 4$ & 0 & 0 & $\begin{array}{c}805 \\
(94.0 \%) \\
\end{array}$ & $\begin{array}{c}51 \\
(6.0 \%) \\
\end{array}$ & $\begin{array}{c}3 \\
(0.4 \%) \\
\end{array}$ & 0 & 0 & 856 \\
\hline $2 ; 5$ & $\begin{array}{c}1 \\
(0.1) \\
\end{array}$ & 0 & $\begin{array}{c}965 \\
(91.8 \%) \\
\end{array}$ & $\begin{array}{c}76 \\
(7.2 \%) \\
\end{array}$ & 0 & $\begin{array}{c}9 \\
(0.9) \\
\end{array}$ & 0 & 1,051 \\
\hline Total & $\begin{array}{c}33 \\
(0.5 \%) \\
\end{array}$ & $\begin{array}{c}12 \\
(0.1 \%) \\
\end{array}$ & $\begin{array}{c}5,528 \\
(87.5 \%)\end{array}$ & $\begin{array}{c}730 \\
(11.6 \%)\end{array}$ & $\begin{array}{c}8 \\
(0.1 \%)\end{array}$ & $\begin{array}{c}13 \\
(0.2 \%)\end{array}$ & 0 & 6,320 \\
\hline
\end{tabular}


Table 5. Frequencies of the lexical and syntactic causatives

\begin{tabular}{|c||c|c||c|}
\hline Age & $\begin{array}{c}\text { Lexical } \\
\text { Causatives }\end{array}$ & $\begin{array}{c}\text { Syntactic } \\
\text { Causatives }\end{array}$ & Total Utterances \\
\hline \hline $1 ; 11-2 ; 1$ & 0 & 0 & 8,797 \\
\hline $2 ; 2-2 ; 4$ & $3(0.02 \%)$ & 0 & 16,661 \\
\hline $2 ; 5-2 ; 7$ & $30(0.23 \%)$ & 0 & 13,324 \\
\hline $2 ; 8-2 ; 10$ & $12(0.08 \%)$ & 0 & 13,833 \\
\hline $2 ; 11-3 ; 1$ & $7(0.07 \%)$ & 0 & 10,086 \\
\hline $3 ; 2-3 ; 4$ & $16(0.12 \%)$ & $2(0.01 \%)$ & 13,564 \\
\hline $3 ; 5-3 ; 7$ & $15(0.13 \%)$ & $1(0.009 \%)$ & 11,427 \\
\hline $3 ; 8-310$ & $9(0.09 \%)$ & $1(0.03 \%)$ & 9,815 \\
\hline $3 ; 11-4 ; 1$ & $12(0.16 \%)$ & $1(0.01 \%)$ & 7,654 \\
\hline $4 ; 2-4 ; 4$ & $3(0.07 \%)$ & 0 & 4,525 \\
\hline $4 ; 5-4 ; 7$ & $3(0.09 \%)$ & $1(0.03 \%)$ & 3,478 \\
\hline $4 ; 8-4 ; 10$ & $8(0.13 \%)$ & $1(0.02 \%)$ & 6,190 \\
\hline $4 ; 11-5 ; 1$ & $6(0.11 \%)$ & $2(0.04 \%)$ & 5,315 \\
\hline $5 ; 2-5 ; 4$ & $10(0.21 \%)$ & $6(0.13 \%)$ & 4,643 \\
\hline $5 ; 5-5 ; 7$ & $3(0.09 \%)$ & $1(0.02 \%)$ & 4,717 \\
\hline $5 ; 8-5 ; 10$ & $7(0.20 \%)$ & 0 & 3,645 \\
\hline $5 ; 11-6 ; 0$ & $3(0.23 \%)$ & 0 & 1,330 \\
\hline \hline Total & $142(0.10 \%)$ & $16(0.01 \%)$ & 139,004 \\
\hline
\end{tabular}

In (55), causatives are all correctly produced. The context of (55a) is that Seizi was crying and Sumihare wanted to explain that it was not Sumihare who made Seizi cry. Here, Seizi is not an agent, as his action, crying, was caused by someone else. The agent is boku (I, or Sumihare), and the object Seizi-kun is scrambled to (or topicalized in) the sentence initial position. Hence, (55a) can be considered to have a monoclausal structure. In (55b), though an indirect object is not present, Sumihare asked his mother to put a pair of shoes directly on him. Thus, in this case, the indirect object Sumihare is a goal, but not as an agent. Then, (55b) is monoclausal. In (55c), kore (this) refers to a fly. In this context, it is not the case that the causee, a fly, died because it intended to. Thus, it is not an agent, and (55c) also has a monoclausal structure. ${ }^{14}$

As in the case of Akkun, Stage IV comes late. Sumihare's syntactic causatives appear after around $3 ; 4$, and become productive after around $4 ; 7 .{ }^{15}$

(56) a. Mou gohan tabe-sase-n yo.

'(I) won't let you eat dinner any more.'

b. Tuke-sase-te age-tara funa-o kure-tan yo. put-Cause let-do as fish-Acc give-Past Int 'As (I, or Sumihare) let (the people fishing) put a net trap (in the water), (they) gave me the fish.'

\footnotetext{
${ }^{14}$ Since Sumihare is a Kansai dialect speaker, he uttered nakasita, hakasite and sinasita instead of nakaseta, hakasete and sinaseta, respectively.

15 From 3;3 through 4;1 we find a few "syntactic causatives" with "wrong" lexical realization (e.g., -se for -sase). Sumihare's syntactic causatives can be considered to be fully acquired after around 4;7.
} 
(56a) and (56b) each have two agents in each structure. In (56a), for example, since Sumihare's utterance is directed to his father, the agent of the action taberu (eat) would be his father. Thus, (56a) can be considered an example of syntactic causatives. In (56b), the agent of the action tuke-ru (put) should be the fishing people (who borrowed Sumihare's net and put it in the water, and gave Sumihare a fish they caught with it later), but not me, or Sumihare. On the other hand, the agent of the action-sase-te age-ta ('letting the fishing people put the net trap') is $I$, or Sumihare. Hence, (56b) also has two agents in the sentence and can therefore be considered a syntactic causative as well.

The number of lexical and syntactic causatives produced by Sumihare and the ratio of the correct causatives to his total utterances at the stages III and IV are given in Table 5.

Table 5 indicates that while, in general, causatives are quite infrequent in natural discourse, lexical causatives are produced much earlier than syntactic causatives.

To sum up, the observational studies reported in previous Japanese acquisition research, Akkun, and Sumihare show the same acquisition process of intransitive verb, (di)transitive verbs, and causatives. Since the children brought up in different periods and in different places show the same acquisition process, it is quite plausible to conjecture that the data described here meets the descriptive adequacy.

The VP-shell analysis can account for the widely observed in the acquisition studies. Children acquire $v$-VP frame structures relatively early, for example, at around 2;6 for Akkun, and at around 1;11 for Sumihare. In Stage I, children lexically realize suru/sita/site (do/did/doing) as the [+cause] $v$. Then, Japanese-speaking children erroneously hypothesize that $[ \pm$ cause] $v$ is phonetically null at one stage in the course of verb acquisition, and make the well-known "mistakes" such as intransitive vs. (di)transitive-alternation and causative-suffix-omission errors. This stage shows the pattern of alternation in English (di)transitive- unaccusative pairs, for example, 'John sank the boat/the boat sank' with the verb sink. Both lexical items in the alternation have the same surface forms. In Murasugi and Hashimoto's hypothesis that both the [+cause] and the [-cause] small v's are realized as zero-morphemes (i.e., without the phonological content) at Stage II, the children's overextension of the verbs cannot be merely morphological and accidental. It is rather the case that the Japanese-speaking children at this stage consider Japanese verbs to be of English sink-type verbs.

We also observed that although children seem to acquire syntactic causatives at around four, they produce isolated examples with $-(s)$ ase much earlier. We argued that they employ $-(s)$ ase as a realization of [+cause] $v$ in those examples. This implies that children assume at one point that the [+cause] $v$ can be realized as $-(s)$ ase along with the other morphemes (such as $-e$ ). It then predicts that the children maintain this assumption even after they acquire -(s)ase as an independent V taking a sentential complement. This is so because it would require some negative evidence to reject their first assumption. Hence, our analysis suggests that -(s)ase can form lexical causatives in addition to syntactic causatives in the adult Japanese. This provides a piece of supportive evidence for Matsumoto (2000), which proposes that there are two - $(s)$ ase causatives in Japanese, namely, lexical and syntactic $-(s)$ ase causatives.

\section{Conclusion}

In this article, we presented acquisition data obtained from our longitudinal studies and Sumihare's database and examined their implications for the analysis of agentive (di)transitive verbs. It was shown that the use of tiyu/tita/tite (do/did/doing) at the early stage provides direct evidence for the analysis based on small $v$ and large $\mathrm{V}$. The elements seem to 
be realizations of the [ + cause] $v$. Then we examined the process of the acquisition of actual lexical items. We suggested that the "mistakes" made at this stage were due to children's assumption that Japanese is exactly like English, that is, that [ \pm cause] $v$ 's are zero morphemes. If the $[ \pm$ cause] $v$ are zero morphemes, then the errors receive a straightforward explanation based on the $v$-VP frame. Finally we discussed the acquisition of syntactic causatives. We proposed that the causative morpheme - $(s)$ ase is used initially as a realization of the [+cause] $v$. This initial use of $-(s)$ ase predicts that it is ambiguous between $\mathrm{V}$ and $v$ in adult Japanese, and we argued that the prediction is indeed borne out.

The discussion in this article, we believe, provided strong support for the $v$-VP frame. According to our analysis, the process of the acquisition of (di)transitive verbs illustrated in this article does not necessarily reflect the acquisition of the predicate-argument structures associated with verbs. The predicate-argument structures of large V's and $v^{\prime}$ s are acquired quite early. What requires time is the acquisition of the lexical form of each $\mathrm{V}$ and more importantly, the forms in which the $\left[{ }^{ \pm}\right.$cause $] v$ 's are realized - the forms develops on the associated large $\mathrm{V}$ in Japanese. This is part of the reason that Japanese-speaking children make the "mistakes" illustrated in sections 2 and 3. As this acquisition process proceeds successfully, they start producing lexical causatives with -(s)ase much before they acquire syntactic causatives.

\section{References}

Baker, Mark (1996). On the structural positions of themes and goals. In Phrase Structure and the Lexicon. J. Rooryck and L. Zaring (eds.), 7-34. Dordrecht: Kluwer Academic Publishers.

Bowerman, Melissa (1974). Learning the structure of causative verbs: A study in the relationship of cognitive, semantic, and syntactic development. Papers and Report on Child Language Development, 8, 142-178.

(1982). Evaluating competing linguistic models with language acquisition data: implications of developmental errors with causative verbs. Quaderni di Semantica, 3, 5-66.

Chomsky, Noam (1995). The Minimalist Program. Cambridge, Mass.: MIT Press.

Figueira, Rosa Attie (1984). On the development of the expression of causativity: A syntactic hypothesis. Journal of Child Language, 11, 109-127.

Fuji, Chisato (2006). Two Types of Causatives in Japanese and Japanese Sign Language: A study in Syntax and Acquisition. M.A. Thesis, Nanzan University.

Hale, Ken. and S. Jay. Keyser (1993). On argument structure and the lexical expression of syntactic relations. In The View from Building 20: Essays in Linguistics in Honour of Sylvain Bromberger. K. Hale and S. J.

Keyser (eds.), 53-109. Cambridge, Mass.: MIT Press.

Ito, Katsutoshi (1990). Kodomo no Kotoba - Shutoku to Souzou. Tokyo: Keisou Shobou.

Ito, Noriko (2005). The longitudinal study of Jun and Shin. ms. Nanzan University.

Kuroda, Sige-Yuki (1965). Causative form in Japanese. Foundation of Language, 1, 30-109.

Larson, Richard (1988). On the double object construction. Linguistic Inquiry, 19, 335-391.

Lord, Carol (1979). 'Don't you fall me down': children's generalization regarding cause and transitivity. Papers and Report on Child Language Development, 17. 81-89.

Matsumoto, Yo (2000). On the crosslinguistic parameterization of causative predicates: Implications from Japanese and other languages. In Argument Realization. M. Butt and T. H. King (eds.), 135-169. Stanford: CSLI Publications.

MacWhinney, Brian (2000). The CHILDES Project: Tools for Analyzing Talk. Mahwah, NJ: Lawrence Erlbaum. Madhavan, Punnappurath (2006). Transitivity alternations and the layered VP. Paper presented at the Hyderabad-Nanzan Joint Workshop, Nanzan University.

Morikawa, Hiromi (1997). Acquisition of Case Marking and Argument Structure in Japanese. Tokyo: Kuroshio Shuppan. 
Murasugi, Keiko and Tomoko. Hashimoto (2004). Three pieces of acquisition evidence for the v-VP frame. Nanzan Linguistics, 1, 1-19.

Murasugi, Keiko, Tomoko, Hashimoto, and Sachiko, Kato (2003). On the acquisition of causatives in Japanese. Online Proceeding Supplement of BUCLD 28.

(2005). On the acquisition of causatives in Japanese. Nanzan Linguistics, 2, 47-60.

Murasugi, Keiko and Nanako Machida (1999).The acquisition of complex predicates: A case study with a Japanese 4-year-child. Academia 66, 381-459. Nanzan University.

Noji, Junya. (1974-1977). Youji no Gengoseikatu no Jittai I-IV. Tokyo: Bunka Hyoron Shuppan.

Okubo, Ai (1967). Youji gengo no hattatsu. Tokyo: Tokyodou Shuppan.

Otsu, Yukio (2002). Gengo no kakutoku. In Gengo Kenkyuu Nyuumon. Otsu, Y., M. Ikeuchi, N. Imanishi, and M. Suiko (eds.), 179-191. Tokyo: Kenkyusha.

Suzuki, Seiichi (1987). Youji no bunpo nouryoku. In Kodomo no Gengo Shinri. Fukuzawa, S (eds.), 141-180. Tokyo: Dainihon Tosho. 